\title{
Tirana 2005
}

\author{
By Ron Holloway \\ Spring 2006 Issue of KINEMA
}

\section{TIRANA INTERNATIONAL SHORT FILM FESTIVAL 2005}

After two strong outings, abetted by the breaking news that Tirana was chosen "World City 2005," it was a sure bet that the Third Tirana International Short Film Festival (5-11 December 2005) would go big time on the world festival stage too. With more than 20,000 Euros in purse prizes as bait, this year's TIFF received over 700 applications from 65 countries for entry in its five sections: 370 in the fiction category, 185 in animation, 85 in documentary, 60 in experimental, and 30 more in the cross-country Albanian-language shorts section. In addition, festival director Ilir Butka and programmer Genc Permeti programmed 27 feature films in free-fall evening programs that ran deep into the night. Most important of all for a festival's continued existence, TIFF 2005 could count on the support of 35 sponsors, plus the city's foreign ambassadors and cultural centres, for the six-day event.

Three juries divided up the awards. The International Jury headed by critic David D'Arcy, awarded 'Best Film of TIFF' to Heiko Hahn's Vorletzter Abschied (Before I Go, Germany), the poignant story of an old couple faced with the woman's shattering Alzheimer illness. Beth Amstrong's Danya (Australia), the story of a young girl's gradual grasp of the reality of death, was awarded Best Fiction Film. Special Mentions for fiction shorts underscored the strength of this category. Robert Bodina's Lulebore (Snowdrop, Albania), a moving tale of a husband's losing effort to raise the money to secure for his ailing wife a life-saving operation abroad, was also voted the Public's Award. Jason Branderburg's 113 (Switzerland) uses a subtle flashback technique to unveil the hidden wartime secrets of a building ("113" is the street address) about to be torn down by wreckers.

Another Special Mention went to Roman Filippov's Posvyashenie (Initiation, Russia). Shot in black-andwhite, it sketches the determination of a sensitive young boy to escape his tormentors on a playground while on his way to a flute rehearsal. A personal favourite was another Russian entry: Vladimir Kott's Dbep (The Door). This absurd Beckettian tale begins with a simpleton emerging from behind a still-standing door after a house has been razed, whereupon he carries the door around on his back like the clowns in Roman Polanski's Two Men and a Wardrobe (Poland, 1959), drawing all and sundry into a merry round of encounters until he disappears behind the door again.

Indeed, the fiction category was the strong suit at TIFF with Spanish entries topping the list for audience appreciation. The Media Award by Albanian critics went to Alex Sampayo's La buena caligrafia (The Good Caligraphy), the story of an illiterate Spanish woman whose desire to learn to read and write leads to a secret about her husband that in the end warms her soul more than distressing her heart. José Javier Rodriguez Melcon's Nana (Lullaby) needs only three minutes to recount the dangerous voyage of asylum-seekers on an open sea, for the mother's lullaby is directed at a sleeping baby in the arms of a frightened young African mother. AndTtokyoBdejo and Jorge C. Dorado's La vvvvGuerra (War), set in World War Two, focuses on the efforts of a young girl to save her baby brother after her parents have been wantonly killed by marauding soldiers.

Equally strong were a handful of entries in the documentary section. Igor Strembitsky's Podorozhniy (Wayfarers, Ukraine), awarded Best Documentary Short, depicts in striking poetic images the everyday in a clinic for the mentally retarded. On the surface Xavier Lukomski's Le pont sur la Drina (The Bridge over the Drina, Belgium) appears to be little more than a one-shot static portrait of a bridge over the River Drina in eastern Bosnia as it emerges from the darkness of night into the light of day, save that the dialogue of a witness at Den Haag pinpoints in chilling terms the death-toll of bodies (men, women, children) that passed nightly under this historic bridge once celebrated in a novel by Nobel Prize winner for literature Ivo Andri. In Maciej Adamek's insightful Powrot (Getting Back, Poland) we follow the faltering efforts of a man to start all over again after serving a 10-year prison term. And Burbuque Berisha's straight-forward Te rritur ne 
rruge (Growing Up in the Streets, Kosovo) the focus is on street-children, some with ailing or jobless parents, making the rounds with produce and wares to make ends meet at home.

Tomek Baginski's Fallen Art (Poland) was awarded Best Animation Short. A multi-festival winner, it depicts the crass attitude of a deranged officer at a military base towards underlings in his command. Another amusing multi-festival winner was Geza M. Toth's Maestro (Hungary), which blends an operatic aria with puppet animation to underscore a closing pun on a "performance" gag. And Erik Rosenlund's Butler (Sweden) spoofs sex and marriage in line drawings about a butler who loses his job when a couple discover that the erotic begins at home base.

Shpend Bengu's Hyrjeß̊Balje (Enter\&EExit, Albania), a black-and-white exercise in flashing images, was awarded Best Experimental Short. And in the new competition for "Albanian Shorts" the entries included productions from Kosovo and the USA. Dhimiter Asmailaj's 89 cents (USA), awarded the top prize, probes the searching subconsciousness of a young student living in New York City.

The Albanian National Centre for Cinematography (ANCC) is currently promoting the launch of a halfdozen newly financed productions and coproduction. Kujtim Cashku's The Magic Eye has already made the rounds of festivals in Cairo, Tel Aviv, and Montreal. Robert Budina's short feature Snowdrop won two prizes at this year's Tirana festival. Artan Minarolli's Chant d'amour, a coproduction with France based on a short story by awarded author Ylljet Alicka, is finished and headed for either Berlin or Cannes. Dhimiter Anagnosti's Father and Godfather, an original script backed solely by ANCC funds, is in post-production. Besnik Bisha's Mao Tse Tung, the story of a boy given this name during the country's link to Red China, is also nearing release. And Fatmir Koci's A King for Circumcision, based on Ismail Kadaré's historical novel Sinister Year, is ready to go before the cameras.

Fatmir Koci, Albania's best known director abroad, was honoured at TIFF 2005 with a three-film retrospective: his short features The Third One (1988) and Ballad Through Bullets (1989), plus the feature Tirana Year Zero (2001). Ken Loach was on hand for the special screening of Tickets (2005), an interwoven train odyssey directed together with Ermanno Olmi and Abbas Kiarostami. Serb director Goran Paskaljevi's Balkan Powder Keg (1999) and Midwinter Night's Dream (2004) were sellout presentations at the Millennium 2 venue. So, too, British documentarist Nick Broomfield's Kurt $\mathscr{E}$ Courtney (1998), his controversial film about rock stars Kurt Cobain and Courtney Love. Last, but not least, seven of Regina Ziegler's Erotic Tales were booked for late hour cineastes.

\section{References}

\section{AWARDS}

Best Film of TIFF

Vorletzter Abschied (Before I Go, Germany)

dir Heiko Hahn - Fiction

Best Fiction Short

Danya (Australia)

dir Beth Armstrong

Special Mentions

Lulebore (Snowdrop, Albania)

dir Robert Bodina

113 (Switzerland)

dir Jason Branderburg

Posvyashenie (Initiation, Russia)

dir Roman Filippov

Best Animation Short

Fallen Art (Poland) 
dir Tomek Baginski

Best Documentary Short

Podorozhniy (Wayfarers, Ukraine)

dir Igor Strembitskyy

Best Experimental Short

HyrjeESDalje (EnterESExit, Albania)

dir Shpend Bengu

Best Albanian Short

89 cents (USA)

dir Dhimiter Ismailaj - Fiction

Brindisi Award

Windows XP (Kosovo)

dir Ujkan Hysaj - Fiction

Media Award

La buena caligrafia (The Good Caligraphy, Spain)

dir Alex Sampayo - Fiction

Public Award

Lulebore (Snowdrop, Albania)

dir Robert Bodina - Fiction

\section{Author Information}

Ron HOLLOWAY (1933-2009) was an American critic, film historian, filmmaker and correspondent who adopted Europe as his home in the early fifties and spent much of his life in Berlin. He was an expert on the study of German cinema and against all odds produced, with his wife Dorothea, the journal German Film, keeping us up-to-date with the work of directors, producers and writers and the showing of German films around the world.

In 2007, Ron Holloway and his wife were awarded the Berlinale Camera Award. Ron also received the Bundesverdienstkreuz (German Cross of Merit), Polish Rings, Cannes Gold Medaille, the American Cinema Foundation Award, the Diploma for Support of Russian Cinema and an honorary award from the German Film Critics' Association.

Ron was also a valued contributor to Kinema for the past fifteen years. 